\title{
Wide circulation of peste des petits ruminants virus in sheep and goats across Nigeria
}

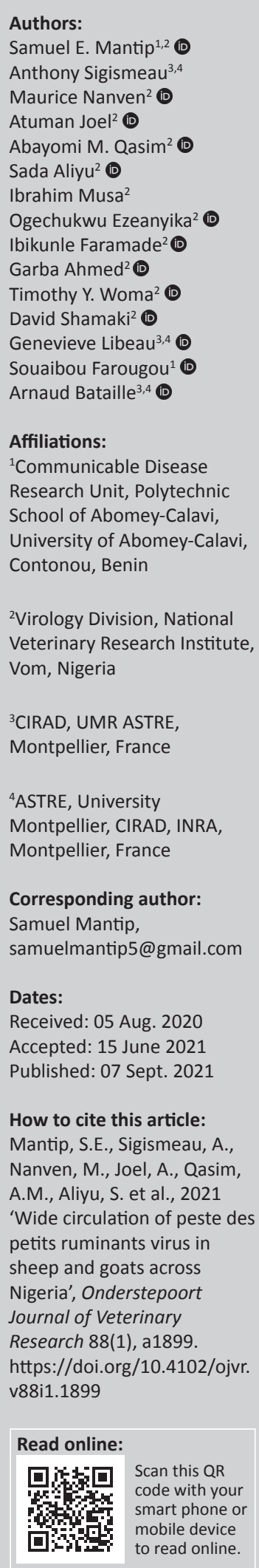

Peste des petits ruminants (PPR) is a highly contagious viral disease that mainly affects goats and sheep in Asia, Africa and the Middle East, and threatens Europe [R.E.1]. The disease is endemic on the African continent, particularly in West Africa, and is a major factor driving food insecurity in low-income populations. The aim of this research study was to carry out surveillance, genetic characterisation and isolation of recently circulating PPR viruses (PPRV) in sheep and goats from the six agro-ecological zones of Nigeria. A total of 268 post-mortem tissue samples of lung and mesenteric ganglia were collected from clinically suspected sheep and goats in 18 different states, of which five never previously sampled. The presence of PPRV was confirmed using a reverse-transcription coupled with a polymerase chain reaction (RT-PCR) assay. A total of 72 samples, 17 sheep (6\%) and 55 goats (21\%), were found to be PPR positive. Positive samples were distributed in almost all states, except Kano, where PPR was detected in previous studies. The PPRV-positive samples were further confirmed by sequencing or virus isolation in areas where the infection had never previously been detected. These results confirm the active circulation of PPRV across all six agro-ecological zones of Nigeria, and consequently, the need for introducing strict measures for the control and prevention of the disease in the country.

Keywords: Peste des petits ruminants; Nigeria; transboundary animal disease; virus isolation; RT-PCR; morbillivirus; sequencing.

\section{Introduction}

Peste des petits ruminants (PPR) is an acute, highly contagious viral disease mainly affecting goats and sheep. The disease was first reported in 1942 by Gargadennec and Lalanne (1942) in sheep and goats that resembled rinderpest in the West African country of Ivory Coast. However, the PPR virus (PPRV) was not isolated until 1967 (Bourdin \& Laurent-Vautier 1968). The PPRV belongs to the family Paramyxoviridae and genus Morbillivirus (Gibbs et al. 1979), with taxonomic name Small ruminant morbillivirus (Amarsingh et al. 2019). This genus currently includes seven known members: measles virus, PPRV, canine distemper virus, seal distemper virus, cetacean morbillivirus, feline morbillivirus and rinderpest virus. In addition to the endemic presence of PPR in sub-Saharan Africa in the past decades, in recent years, field data and laboratory findings have confirmed the dramatic southward spread of PPR, affecting Gabon, the Democratic Republic of Congo, Somalia, Kenya and Tanzania (Swai et al. 2009). An outbreak of PPR infection was reported in Angola for the first time in October 2012 and in Zambia in July 2015 (Baron et al. 2016). The risk of introduction of PPR is now high in neighbouring countries with major sheep and goat populations, such as the Republic of South Africa and Mozambique. In addition to Africa, PPR infection has been reported in many Asian countries, including China. After an initial identification in Tibet in 2007 (Wang et al. 2009), a major PPR epizootic was reported there in 2013-2014 (Bao et al. 2017). As PPR has an economic impact, it is on the list of notifiable diseases to the International Office of Epizootics (OIE, World Animal Health Organization, https://www.oie.int) in the event of emergence. It is now the subject of a worldwide eradication campaign by OIE and FAO-UN (Food and Agriculture Organization of the United Nations; FAO \& OIE 2015). PPRV transmission is only horizontal, by contact, which can be direct or indirect. Indirect transmission of the virus can be through ingestion of food or contaminated water or aerosolised transmission (Libeau et al. 2014). Goats are usually more sensitive than sheep, which have a higher recovery rate (Khan et al. 2009). Symptoms include fever, oculo-nasal discharge, diarrhea, dyspnoea, and effusion of the epithelium of the oral and nasal mucous membranes. Nasal and ocular discharges become mucopurulent, which causes a faint odour (Wohlsein \& Saliki 2006). The rate of PPRV-related morbidity in a flock can reach 100\%, and mortality is estimated at $90 \%$ (Singh et al. 2009). PPRV is classified into four genetically distinct lines, 'lineage I' to 'lineage IV', and all four are currently circulating in Africa (Mantip et al. 2016). 
In Nigeria, sheep and goats are widespread across different ecological and climatic zones of the country. It is estimated that these animals provide more than $35 \%$ of total animal protein consumption in the country (Mantip et al. 2016). The total industrial value of small ruminants in Nigeria is around 40 billion naira ( $€ 100$ million (euros), Shamaki 2002). The results obtained in previous studies suggest that PPR remains an endemic disease in the country, accompanied by sporadic epidemics. Strains of PPRV of both lineages II and IV have been found to circulate in Nigeria in 2012. However, areas where the disease was considered as being exotic in the past could be the places today of regular epidemics because of an increase in trade and commerce. The aim of this research study was to provide an update on PPR circulation and epidemiology in sheep and goats across Nigeria using molecular diagnostics and virus isolation.

\section{Materials and methods \\ Study area}

The study area included all six agro-ecological zones of Nigeria: north-central, north-west, north-east, south-west, south-east and south-south. In order to obtain a representative sample of sheep and goat flocks in the country, samples were collected in three states in each agro-ecological zone.
Sampling was conducted between 2017 and 2018 in 18 states: Bauchi, Adamawa, Taraba, Kano, Kebbi, Katsina, Plateau, Kwara, Benue, Oyo, Osun, Ogun, Abia, Anambra, Enugu, Akwa Ibom, Cross River and Rivers (Figure 1 and Table 1).

Sampling was carried out in each of these states by moving from one market place to another, with markets having been judged to be the most important location for sampling in each state. Target sampling size was 60 samples per zone and 20 locations per state. The sampling location was mapped using GPS coordinates. Goats and sheep suspected of being infected by PPR were identified based on clinical symptoms, which included fever over $40{ }^{\circ} \mathrm{C}$, weight loss, ocular-nasal discharge and diarrhea. Veterinarians belonging to the Nigerian national veterinary services conducted the field studies in accordance with local legislation. The suspected animals were purchased from their owners, systematically euthanised, and an autopsy was performed to collect tissue samples. In addition, samples were collected from slaughterhouses located near the markets. The tissue samples collected from most animals had visible traces of diarrhea and oculo-nasal discharges on their carcasses. The tissue samples were immediately packed with ice and ice accumulators, and transported to the PPR laboratory of the National Veterinary Research Institute, Vom, Plateau State,

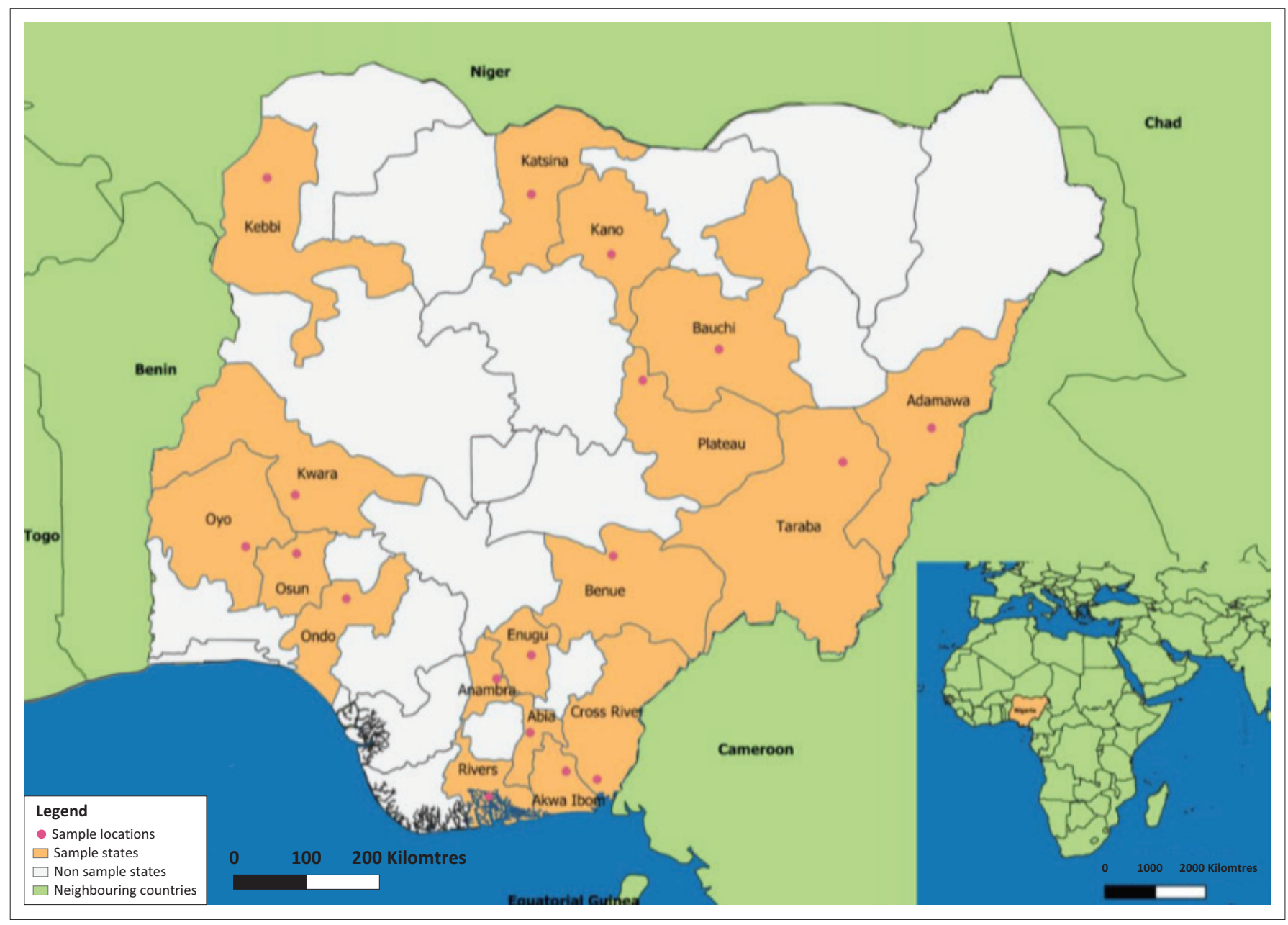

FIGURE 1: Sampling locations in different states of Nigeria over the period 2017-2018. 
TABLE 1: List of Peste des petits ruminants viruses-positive samples and partial $\mathrm{N}$ gene sequences obtained during this study.

\begin{tabular}{|c|c|c|c|c|c|}
\hline Location & Species & Sample & $\mathbf{N}$ & Year & $\begin{array}{l}\text { Accession } \\
\text { number }\end{array}$ \\
\hline \multicolumn{6}{|c|}{ North-central zone } \\
\hline Plateau state & Goat & $\mathrm{Lg}, \operatorname{Ln}$ & $8 / 20$ & 2017-2018 & - \\
\hline Benue state & Goat & $\mathrm{Lg}, \mathrm{Ln}$ & $2 / 20$ & 2018 & - \\
\hline \multirow[t]{2}{*}{ Kwara state } & Goat & $\mathrm{Lg}, \mathrm{Ln}$ & $3 / 17$ & 2017-2018 & - \\
\hline & Sheep & $\mathrm{Lg}, \operatorname{Ln}$ & $0 / 3$ & 2017-2018 & - \\
\hline \multicolumn{6}{|l|}{ North-east zone } \\
\hline \multirow[t]{2}{*}{ Bauchi state } & Goat & $\mathrm{Lg}, \operatorname{Ln}$ & $4 / 15$ & 2017-2018 & - \\
\hline & Sheep & $\mathrm{Lg}, \mathrm{Ln}$ & $1 / 5$ & 2017-2018 & - \\
\hline \multirow[t]{2}{*}{ Adamawa state } & Goat & $\mathrm{Lg}, \mathrm{Ln}$ & $0 / 12$ & 2017-2018 & - \\
\hline & Sheep & $\mathrm{Lg}, \operatorname{Ln}$ & $1 / 8$ & $2017-2018$ & - \\
\hline \multirow[t]{2}{*}{ Taraba state } & Goat & $\mathrm{Lg}, \operatorname{Ln}$ & $2 / 14$ & 2017-2018 & - \\
\hline & Sheep & $\mathrm{Lg}, \mathrm{Ln}$ & $0 / 6$ & 2017-2018 & - \\
\hline \multicolumn{6}{|l|}{ North-west zone } \\
\hline \multirow[t]{2}{*}{ Kano state } & Goat & $\operatorname{Lg}, \operatorname{Ln}$ & $0 / 14$ & $2017-2018$ & - \\
\hline & Sheep & $\operatorname{Lg}, \operatorname{Ln}$ & $0 / 6$ & $2017-2018$ & - \\
\hline \multirow[t]{2}{*}{ Katsina state } & Goat & $\operatorname{Lg}, \operatorname{Ln}$ & $3 / 13$ & 2017-2018 & MT193237 \\
\hline & Sheep & $\mathrm{Lg}, \mathrm{Ln}$ & $1 / 7$ & 2017-2018 & - \\
\hline \multirow[t]{2}{*}{ Kebbi state } & Goat & $\operatorname{Lg}, \operatorname{Ln}$ & $5 / 6$ & 2018 & MT193247 \\
\hline & Sheep & $\mathrm{Lg}, \mathrm{Ln}$ & $7 / 14$ & 2018 & - \\
\hline \multicolumn{6}{|l|}{ South-east zone } \\
\hline \multirow[t]{2}{*}{ Enugu state } & Goat & $\mathrm{Lg}, \mathrm{Ln}$ & $2 / 11$ & 2018 & MT193249 \\
\hline & Sheep & $\mathrm{Lg}, \mathrm{Ln}$ & $1 / 9$ & 2018 & - \\
\hline \multirow[t]{2}{*}{ Abia state } & Goat & $\mathrm{Lg}, \mathrm{Ln}$ & $3 / 13$ & 2018 & MT193250 \\
\hline & Sheep & $\mathrm{Lg}, \mathrm{Ln}$ & $4 / 7$ & 2018 & - \\
\hline \multirow[t]{2}{*}{ Anambra state } & Goat & $\mathrm{Lg}, \mathrm{Ln}$ & $6 / 13$ & 2018 & - \\
\hline & Sheep & $\mathrm{Lg}, \mathrm{Ln}$ & $3 / 7$ & 2018 & - \\
\hline \multicolumn{6}{|l|}{ South-west zone } \\
\hline Oyo state & Goat & $\operatorname{Lg}, \operatorname{Ln}$ & $5 / 20$ & 2018 & - \\
\hline Ondo state & Goat & $\mathrm{Lg}, \operatorname{Ln}$ & $1 / 20$ & 2018 & - \\
\hline Osun state & Goat & $\mathrm{Lg}, \operatorname{Ln}$ & $3 / 20$ & 2018 & - \\
\hline \multicolumn{6}{|c|}{ South-south zone } \\
\hline Rivers state & Goat & $\mathrm{Lg}, \mathrm{Ln}$ & $1 / 20$ & 2018 & MT193235 \\
\hline $\begin{array}{l}\text { Cross-rivers } \\
\text { state }\end{array}$ & Goat & $\mathrm{Lg}, \mathrm{Ln}$ & $2 / 20$ & 2018 & - \\
\hline $\begin{array}{l}\text { Akwa-lbom } \\
\text { state }\end{array}$ & Goat & $\mathrm{Lg}, \operatorname{Ln}$ & $4 / 20$ & 2018 & - \\
\hline Total & - & - & $73 / 360$ & - & 22 \\
\hline
\end{tabular}

Note: Location is the town where the samples were collected or the main town closest to the sampling site. Type indicates if samples were collected from a flock or in market. $N$ is the number of positive samples or total samples tested. Accession number, market. Nis the number of positive samples or total samples tested. Accession number, Gen mank accession number Accession numbers are repeated when the same sequence was obtained from severa Accession numbers are repeated when the same sequence was obtained from several locations. The total accession number refers to the total number of non-identical sequences obtained.

Lg, lung; Ln, lymph node.

Nigeria, and stored in a freezer at $-70{ }^{\circ} \mathrm{C}$ before the sampling team moved on to another state. The samples were subsequently shipped to CIRAD, Montpellier, France for further laboratory analyses.

\section{Molecular detection of the virus nucleic acid}

Tissue samples were cut into pieces and ground in $3 \mathrm{~mL}$ of Minimum Essential Medium (MEM) by vortexing with $0.2 \mu \mathrm{m}$ glass beads. The swabs were placed in $1 \mathrm{~mL}$ MEM and vortexed. In all cases, the sample suspensions were centrifuged for $3 \mathrm{~min}$ at $1000 \mathrm{~g}$ and the supernatant was collected. Total ribonucleic acid (RNA) was extracted with an extraction robot KingFisher ${ }^{\mathrm{TM}}$ and ID Kit Gene ${ }^{\mathrm{TM}}$ Mag Universal Extraction (IDvet, France), as described by the manufacturer. The molecular diagnosis of PPR for each sample was performed by reverse-transcription coupled with a polymerisation chain reaction (RT-PCR) that uses the pair of primers NP3 (5'-GTC-TCG-GAA-ATC-GCC-TCACAG-ACT-3') and NP4 (5'-CCT-CCT-CCT-GGT-CCT-CCAGAA-TCT-3') that specifically target the partial $\mathrm{N}$ gene (Couacy-Hymann et al. 2002). The RT-PCR was performed using Quantabio qTXT XLT One-Step RT-PCR kit, following manufacturer's instruction. The RT-PCR mixture $(25 \mu \mathrm{L})$ was composed of $5 \mu \mathrm{L}$ RNA, $12.5 \mu \mathrm{L}$ of One-Step Tough-Mix (2X), $1.5 \mu \mathrm{L}$ of NP3 $10 \mu \mathrm{M}, 1.5 \mu \mathrm{L}$ of NP4 $10 \mu \mathrm{M}, 1 \mu \mathrm{L}$ of qScript XLT 1-Step RT 25X, $3.5 \mu \mathrm{L}$ of $\mathrm{H}_{2} \mathrm{O}$ and $5 \mu \mathrm{L}$ of nucleic acids from each sample. The RT-PCR cycle programme consisted of RT for $20 \mathrm{~min}$ at $48{ }^{\circ} \mathrm{C}$, denaturation for $3 \mathrm{~min}$ at $94{ }^{\circ} \mathrm{C}$; 40 cycles of $15 \mathrm{~s}$ at $94{ }^{\circ} \mathrm{C}, 30 \mathrm{~s}$ at $60^{\circ} \mathrm{C}$ and final extension for 1 $\min$ at $72{ }^{\circ} \mathrm{C}$.

The presence of PCR product of the expected size ( $355 \mathrm{bp}$ ) was controlled by $1.5 \%$ agarose gel migration. The fragment size of our amplicon was monitored using a 100-bp molecular weight marker after illumination under UV radiation or blue light.

\section{Phylogenetic analysis}

When positive PCR products were obtained from areas where PPR had never previously been detected (Kebbi, Katsina, Rivers, Enugu and Abia states; see the Results section), one positive sample per state was selected based on the brightness of the amplicon on the gel, and sent to GENEWIZ (United Kingdom) for purification and sequencing in both forward and reverse directions. The sequences were submitted to the NCBI GenBank database (Table 1). Forward and reverse deoxyribonucleic acid (DNA) sequences were assembled using BioEdit and trimmed to remove poor-quality portions of the sequences (final size $=255$ base pairs [bp]). Corrected sequences were aligned with a dataset of PPRV $\mathrm{N}$ gene sequences publicly available in GenBank using MEGA 6 representatives of the four genetic lineages.

The phylogenetic tree was constructed using the maximum likelihood method implemented in MEGA 6, with node supports evaluated by bootstrap analyses with 1000 replicates.

\section{Cell culture and virus isolation}

Virus was isolated from field samples on canine histiocytic sarcoma (CHS) cells using the same five PCR positive samples sent for sequencing. CHS cells are CV1 cells (monkey cell line) modified to express SLAM receptors ('Signaling Lymphocytic Activation Molecule'), or CD150 of goats, which are highly sensitive to PPRV growth (Adombi et al. 2011). These cells, which are very sensitive to PPRV infection, were used to isolate the virus from field samples. Five samples from different states that showed strong PCR amplification results were selected for the isolation attempt. Aliquots $(150 \mathrm{~mL})$ of viral solution contained in the homogenate samples were inoculated into the $\mathrm{CHS}$ cell mat seeded at a minimum confluence of $70 \%$ in $25 \mathrm{~cm}^{2}$ flasks.

The flask was gently shaken at 15-min intervals for $1 \mathrm{~h}$. Culture medium was composed of MEM, foetal calf serum 
(FCS), an antibiotic and antimycotic was added. Antibiotics and antimycotics help to protect cells from potential contamination by pathogens (bacteria, fungi, etc.) that may be present in the sample. The infected flasks were incubated with $5 \% \mathrm{CO}_{2}$ at $37^{\circ} \mathrm{C}$. The cytopathogenic effect (CPE) occurs after varying intervals because of the different viral loads in the samples. Incubation was stopped when the CPE reached $80 \%$ (Figure 3), and the flasks were subjected to cycles of freezing $\left(-80{ }^{\circ} \mathrm{C}\right.$ ) and thawing (at room temperature or ambient temperature). These cycles cause the cells to burst and release viral particles. Culture medium that contained dead cells and viral particles was collected and centrifuged. The supernatant of the culture medium was used to extract the total nucleic acids as explained above.

Some samples showed bacterial or fungal contamination during the first isolation attempt. A second attempt, including an additional filtration step and the addition of a second antibiotic, was, therefore, necessary. The size of the filter pores used was $0.45 \mathrm{~mm}$. The bacteria are all retained by pores of this size. The second antibiotic used was gentamycin. Subsequently, the presence of the virus in the medium was confirmed by collecting and testing the cell culture supernatant by RT-PCR.

\section{Ethical considerations}

Approval to conduct the study was received from the Ethics Committee: National Veterinary Research Institute, Animal Use and Care Committee (AUCC, NVRI, Vom; reference No. AEC/02/87/20). Approval was also received from the University of Abomey-Calavi, Benin Republic.

\section{Results}

Total nucleic acids were extracted from a total of 268 samples taken from 18 different states. Amplification of the target gene by RT-PCR using the pair of PPRV primers was successful for 73 samples (27\%; Table 1). At least one sample was positive for PPRV of samples from 17 states: Plateau, Benue, Kwara, Bauchi, Adamawa, Taraba, Katsina, Kebbi, Enugu, Abia, Anambra, Oyo, Ondo, Osun, Rivers, Cross River and Akwa-lbom. None of the samples were found to be positive amongst the 20 samples from Kano state (Table 1). Amongst the positive samples, 17 came from sheep (6\%) and 55 from goats (21\%). The sequence of the partial $\mathrm{N}$ gene was successfully obtained from one sample each collected from the states of Kebbi, Katsina, River, Enugu and Abia. Phylogenetic analysis showed that all five samples sequenced in this study belonged to lineage IV and clustered with a strain collected in Nigeria in 2013 (Figure 2; Woma et al. 2016) (R.E.4). The CPE was observed in only one out of the five samples used in the isolation attempt, which included the sample from the state of Kastina. The presence of PPRV in the cell culture was confirmed by RT-PCR (Figure 3).

\section{Discussion}

Since they found that PPR as a disease in sheep and goats for the first time in Nigeria in 1973, and the eventual successful isolation of the virus in 1975 (Taylor \& Abegunde 1979), the disease has remained a major threat for small ruminant production and has had negative impacts on food security, with PPR being the most economically important livestock disease in Nigeria.

Even though PPR has been of concern in the Nigerian livestock sector for a long time now, surprisingly few studies have been carried out to understand the molecular epidemiology of the disease in Nigeria. Additionally, the few studies that were conducted did not get as far as isolating and sequencing the isolates. Exceptions concern the virus detected and isolated in 1975 (Taylor \& Abegunde 1979) and the molecular virus detection in 2002 (Shamaki 2002) that were found to cluster within lineage II. The results of this study provide evidence for the continued circulation of PPR across all six agro-ecological zones of Nigeria. The presence of PPRV was detected by N-genebased RT-PCR in $27 \%(72 / 268)$ of random geo-spatially suspected samples, proving the circulation of PPRV in the

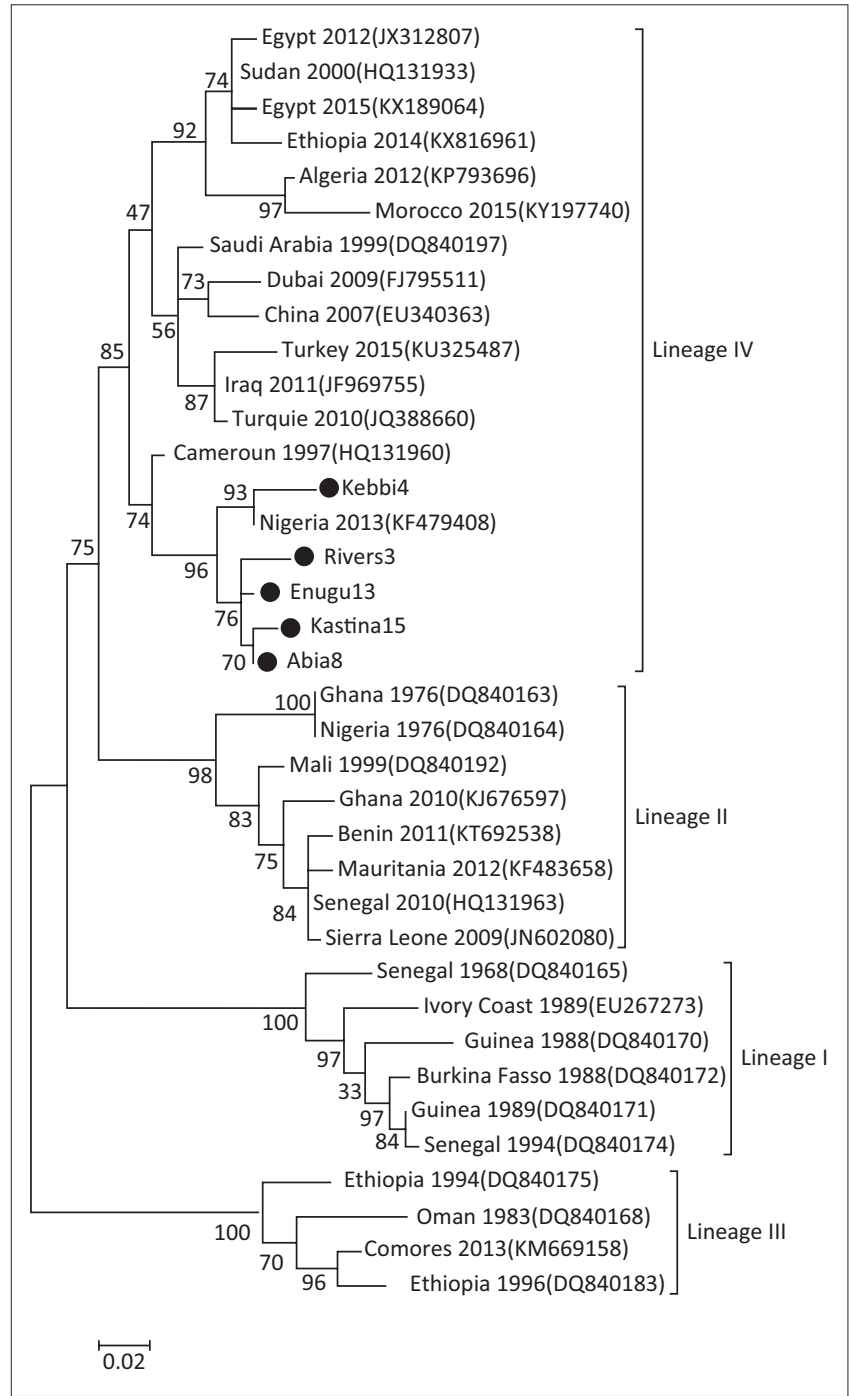

FIGURE 2: Phylogenetic tree of the partial $\mathrm{N}$ gene of Peste des petits ruminants viruses strains derived from samples in Nigeria and publicly available sequences. The sequences obtained in this study are indicated with a black dot. The numbers at the nodes are bootstrap values obtained from 1000 replicates are shown if $>50 \%$. 

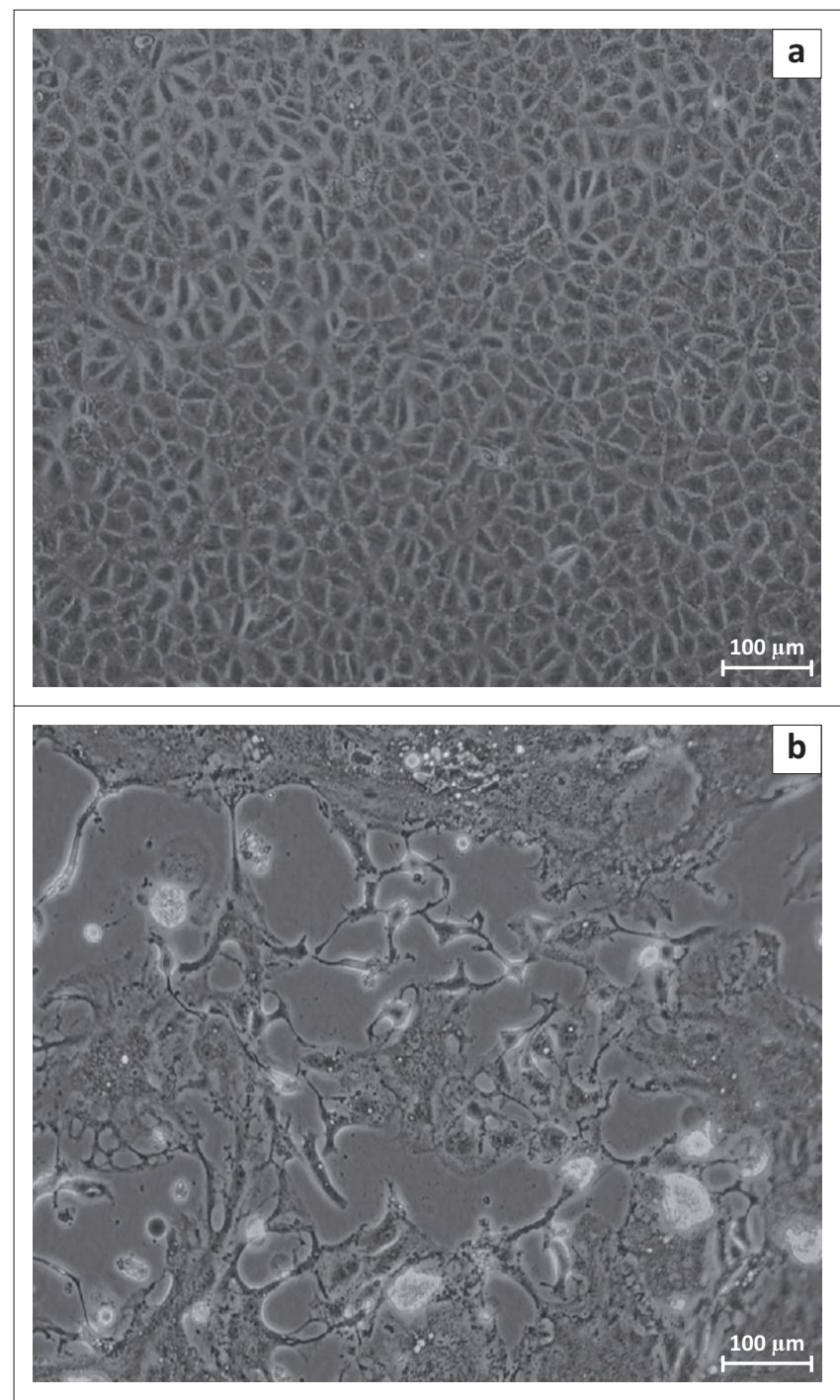

FIGURE 3: Canine histiocytic sarcoma cells at $100 \%$ confluence observed under a light microscope, $\times 100$ magnification, when (a) non-infected or (b) with cytopathic effect (CPE) because of Peste des petits ruminants viruses infection.

study areas. Notably, we provide the first molecular confirmation of the presence of PPRV in the south-east agro-ecological zone.

In a similar previous study, a total of 35 samples out of 360 $(9.7 \%)$ tested positive using RT-PCR, of which 25 were from oculo-nasal swabs and 10 were from tissue samples (Mantip et al. 2016). Similar previous studies using clinical cases in Ethiopia reported a positivity rate of $46.4 \%$ using RT-PCR (Alemu et al. 2019). In Morocco, a similar study reported a PPR positivity rate of $44.4 \%(16 / 36)$ using RT-PCR and a positivity rate of $80 \%$ in Sudan (Kwiatek et al. 2011). The presence of PPRV was also confirmed in 33.3\% (7/21) and $51.2 \%(17 / 33)$ of clinical samples tested in Algeria and in north-central state in Nigeria, respectively, using a set of primers specific to the F gene of the PPRV (De Nardi et al. 2012). In northern and eastern Tanzania, the PPRV genome was also detected in $29.6 \%$ and $31.1 \%$ of the goats tested (Kgotlele et al. 2014). However, it has been shown that the level of positivity can be influenced by the type of sample used for diagnosis, the stage of infection and the type of gene targeted for RT-PCR (Luka et al. 2012). Such comparisons consequently only provide limited information to assess the RT-PCR technique or to provide details on the prevalence of the disease. Furthermore, as the data are provided by studies conducted in difficult field environments, $100 \%$ success is not feasible for the following reasons: (1) samples are not collected at the right time, as the locations of the outbreak are usually reached too late for antigen-gene detection, that is, the window for PCR diagnosis is too narrow; (2) according to these publications, the samples are stored differently: the shorter the harvest campaign, the faster the samples will be kept at the right temperature; (3) viral loads fluctuate depending on the host species and breed, as well as on the virulence of the PPRV strain, as demonstrated in experimental (Couacy-Hymann et al. 2007; Couacy-Hymann et al. 2009) and natural infections.

This study revealed a significantly higher rate of PPRV infection in goats than in sheep samples with RT-PCR, with 17 positive samples obtained from sheep (6\%) compared with 55 (21\%) from goats. The PPRV exhibits more or less similar levels of virulence in sheep and goats; however, goats are more severely affected, whilst sheep generally suffer from a milder form (Lefevre \& Diallo 1990) or rarely suffer from a clinical disease (Fakri et al. 2017; El Hag Ali \& Taylor 1984; Roeder et al. 1994). Nevertheless, high mortality rates were reported in sheep during an outbreak by Taylor (1984) who hypothesised that sheep possess innate resistance to the clinical effects of the disease; however, that occasional field strains can overcome this resistance resulting in high mortality rates (El Hag Ali \& Taylor 1984). Breed may also affect the outcome of PPRV infection and its epidemiology; Guinean breeds (West African dwarf, Iogoon, Kindi and Djallonke) are known to be highly susceptible (Lefevre \& Diallo 1990). British breeds exhibited severe clinical reactions when experimentally infected, whereas Sudanese breeds failed to develop a characteristic clinical response (El Hag Ali \& Taylor 1984).

It has been suggested that PPRV be isolated from field samples in cell culture for further identification (FAO \& OIE 2015; Lefevre et al. 1990). This study showed that the inoculation, isolation and propagation of PPRV in CHS-20 cells succeeded from the first passage of one of the selected positive samples, with the CPE characteristic in agreement with that described by the World Organisation for Animal Health (OIE 2019; Adombi et al. 2011). The presence of the virus in the CHS-20 medium was confirmed by collecting and testing the cell culture supernatant by RT-PCR.

Molecular characterisation of the circulating strains by phylogenetic analysis using the $\mathrm{N}$ gene is the most accurate way of identifying the lineage genetics belonging to new strains. This tool is important in understanding the epidemiology of PPRV and in tracking outbreaks in PPRprone and endemic countries. Such information helps to establish the diversity and circulation of strains in the field, thereby tracing the space-time origin of PPRV and making it 
possible to estimate the risk of its introduction in the herd (Libeau et al. 2014). This study presents the first molecular confirmation of PPR infection in the states of Kebbi and Kastina (north-west), Abia and Enugu (south-east), and Rivers (south-south) in Nigeria. The sequences obtained showed that the samples tested belong to lineage IV. Previous studies showed that both lineages II and IV were circulating in neighbouring states in 2010-2012 (Mantip et al. 2016; Woma et al. 2016). Further sequencing of PPR-positive samples is needed to assess whether lineage II is still circulating in any of these five states.

The successful molecular findings and virus isolation in this study confirm the active presence of PPRV infections amongst populations of sheep and goats in all six agroecological zones, suggesting that PPR is currently endemic virtually everywhere in Nigeria. We, therefore, recommend systematic vaccination with thorough investigation of outbreaks and surveillance to contain outbreaks within the affected locations, states and regions of the country. We also recommend strengthening of the surveillance system, with emphasis on early detection, in epidemiologically closely linked administrative units (local government areas) to which the disease could potentially spread. Such interventions should be in line with broader regional and national control programmes for PPR in Africa.

\section{Acknowledgements Competing interests}

The authors declare that they have no financial or personal relationships that may have inappropriately influenced them in writing this article.

\section{Authors' contributions}

S.E.M., A.B., G.L., D.S. and S.F. conceived and planned the experiments. S.E.M., M.N., A.J., A.M.Q., S.A., I.M., O.E., I.F. and G.A. collected the samples. S.E.M. and A.S. performed laboratory analyses. S.E.M., A.S. and A.B. analysed the results. S.E.M., A.S., A.B., D.S., T.Y.W., G.L. and S.F. interpreted the results. S.E.M. and A.B. wrote the first draft of the manuscript. All co-authors critically revised and approved the final version of the manuscript.

\section{Funding information}

This research article was funded by the European Commission Directorate General for Health and Food Safety (Grant No. SI2.756606) awarded to the European Union Reference Laboratory for Peste des Petits Ruminants (EURL-PPR) and by a grant from European Commission (Development Cooperation Instruments) awarded to the project 'EU Support to Livestock Disease Surveillance Knowledge Integration - LIDISKI' (FOOD/2019/410-957) in the framework of the Development of Smart Innovation through Research in the Agriculture (DeSIRa) programme.

\section{Data availability}

The data supporting the findings of this study are freely available in GenBank at https://www.ncbi.nlm.nih.gov/ (accession numbers: MT193235, MT193237, MT193247, MT193249 and MT193250).

\section{Disclaimer}

The views expressed in the article are those of the authors and not an official position of the institution or funder.

\section{References}

Adombi, C.M., Lelenta, M., Lamien, C.E., Shamaki, D., Koffi, Y.M., Traore, A. et al., 2011, 'Monkey CV1 cell line expressing the sheep-goat SLAM protein: A highly sensitive cell line for the isolation of peste des petits ruminants virus from doi.org/10.1016/j.jviromet.2011.02.024

Alemu, B., Gari, G., Libeau, G., Kwiatek, O., Kidane, M., Belayneh, R. et al., 2019, 'Molecular detection and phylogenetic analysis of Peste des petits ruminants virus circulating in small ruminants in eastern Amhara region, Ethiopia', BMC Veterinary Research 15, 84. https://doi.org/10.1186/s12917-019-1828-6

Amarasinghe, G.K., Bào, Y., Basler, C.F., Bavari, S., Beer, M., Bejerman, N. et al., 2017 , 'Taxonomy of the order Mononegavirales: Update 2017', Archives of Virology 162, 2493-2504. https://doi.org/10.1007/s00705-017-3311-7

Bao, J., Wang, Q., Li, L., Liu, C., Zhang, Z., Li, J. et al., 2017, 'Evolutionary dynamics of recent peste des petits ruminants virus epidemic in China during 2013-2014', Virology 510, 156-164. https://doi.org/10.1016/j.virol.2017.07.018

Bourdin, P. \& Laurent-Vautier, A., 1968, 'Note sur la structure du virus de la peste des petits ruminants (in French)', Revue d'élevage et de médecine vétérinaire des pays tropicaux 20(3), 383-386. https://doi.org/10.19182/remvt.7469

Couacy-Hymann, E., Roger, F., Hurard, C., Guillou, J.P. \& Libeau, G., 2002, 'Rapid and sensitive detection of peste des petits ruminants virus by a polymerase chain reaction assay', Journal of Virology Methods 100(1-2), 17-25. https://doi. reaction assay', Journal of Virology
org/10.1016/S0166-0934(01)00386-X

De Nardi, M., Lamin Saleh, S.M., Batten, C., Oura, C., Di Nardo, A. \& Rossi, D., 2012 'First evidence of peste des petits ruminants (PPR) virus circulation in Algeria (Sahrawi territories): Outbreak investigation and virus lineage identification' Transboundary Emerging Disease 59(3), 214-222. https://doi.org/10.1111/ j.1865-1682.2011.01260.x

El Hag Ali, B. \& Taylor, W.P., 1984, 'The isolation of peste des petits ruminants virus from the Sudan', Research in veterinary Science 36(1), 1-4. https://doi. org/10.1016/S0034-5288(18)31991-X

FAO \& OIE, 2015, Global control and eradication of PPR, viewed 30 December 2020, from http://www.oie.int/eng/PPR2015/doc/PPR-Advocacy-EN.pdf.

Gargadennec, L. \& Lalanne, A., 1942, 'La peste des petits ruminants', Bulletin des Services Zoo Technique et des Epizootie de l'Afrique Occidentale Française 5, 16-21.

Gibbs, E.P., Taylor, W.P., Lawman, M.J. \& Bryant, J., 1979, 'Classification of peste des petits ruminants virus as the fourth member of the genus Morbillivirus', Intervirolology 11, 268-274. https://doi.org/10.1159/000149044

Kgotlele, T., Macha, E.S., Kasanga, C.J., Kusiluka, L.J., Karimuribo, E.D., Van Doorsselaere, J. et al., 2014, 'Partial genetic characterization of peste des petits ruminants virus from goats in northern and eastern Tanzania', petits ruminants virus from goats in northern and eastern Tanzania',
Transboundary and Emerging Diseases 61(Suppl 1), 56-62. https://doi org/10.1111/tbed.12229

Khan, H.A., Siddique, M., Arshad, M., Abubakar, M., Akhtar, M., Arshad, M.J. et al., 2009, 'Post-vaccination antibodies profile against Peste des petits ruminants (PPR) virus in sheep and goats of Punjab, Pakistan', Tropical Animal ruminants (PPR) virus in sheep and goats of Punjab, Pakistan', Tropical Animal
Health and Production 41, 427-430. https://doi.org/10.1007/s11250-008Health and $922-6$

Kwiatek, O., Ali, Y.H., Saeed, I.K., Khalafalla, A.I., Mohamed, O.I., Abu Obeida, A. et al., 2011, 'Asian lineage of peste des petits ruminants virus, Africa', Emerging Infectious Disease 17(7), 1223-1231. https://doi.org/10.3201/eid1707.101216

Lefevre, P.C. \& Diallo, A., 1990, 'Peste des petits ruminants', Revue Scientifique et Technique 9(4), 935-981. https://doi.org/10.20506/rst.9.4.532

Libeau, G., Diallo, A. \& Parida, S., 2014, 'Evolutionary genetics underlying the spread of peste des petits ruminants virus', Animal Frontiers 4(1), 14-20. https://doi. org/10.2527/af.2014-0003

Luka, P.D., Erume, J., Mwiine, F.N. \& Ayebazibwe, C., 2012, 'Molecular characterization of peste des petits ruminants virus from the Karamoja region of Uganda (2007-2008)', Archives of Virology 157, 29-35. https://doi.org/10.1007/ s00705-011-1135-4

Mantip, S., Quan, M., Shamaki, D. \& Van Vuuren, M., 2016, 'Comparison of nucleotide sequences of recent and previous lineages of peste-des-petits-ruminants viruses of sheep and goats in Nigeria', Onderstepoort Journal of Veterinary Research 83(1), 1163. https://doi.org/10.4102/ojvr.v83i1.1163

OIE, 2019, 'Peste des petits ruminants', in Manual of diagnostic tests and vaccines for terrestrial animal health', viewed 30 December 2020, from https://www.oie. int/en/what-we-do/standards/codes-and-manuals/terrestrial-manual-onlineaccess/. 
Roeder, P.L., Abraham, G., Kenfe, G. \& Barrett, T., 1994, 'Peste des petits ruminants in Ethiopian goats', Tropical Animal Health and Production 26, 69-73. https://doi. org/10.1007/BF02239901

Shamaki, D., 2002, 'Serological and molecular epidemiology of peste des petits ruminants (PPR) in Nigeria', Ph. D thesis in the department of Veterinary Microbiology, University of Ibadan, Nigeria.

Singh, R.K., Balamurugan, V., Bhanuprakash, V., Sen, A., Saravanan, P. \& Pal Yadav, M. 2009 , 'Possible control and eradication of peste des petits ruminants from India: Technical aspects', Veterinaria Italania $45,449$.
Taylor, W.P. \& Abegunde, A., 1979, 'The isolation of peste des petits ruminants virus from Nigerian sheep and goats', Research in Veterinary Sciences 26(1), 94-96. https://doi.org/10.1016/S0034-5288(20)30949-8

Wohlsein, P. \& Saliki, J., 2006, 'Rinderpest and plague of small ruminants - The diseases', in T. Barret, P-P. Pastoret \& W.P. Taylor (eds), Rinderpest and peste of small ruminants, Academic Press, pp. 68-V. https://doi.org/10.1016/B978-012088385-1/50034-4

Woma, T.Y., Adombi, C.M., Yu, D., Qasim, A.M.M., Sabi, A.A., Maurice, N.A. et al., 2016 , 'Co-circulation of Peste-des-Petits-Ruminants virus Asian lineage IV with lineage II in Nigeria', Transboundary and Emerging Diseases 63(3), 235-242. https://doi. 